\title{
NARZĘDZIA CYFROWE W EKSPERTYZIE ODBITEK GRAFICZNYCH: ZREALIZOWANE PROJEKTY ORAZ MOŻLIWOŚCI ICH ROZWINIECCIA NA POTRZEBY STUDIÓW WIZUALNYCH
}

Analiza papieru jest jedną z podstawowych metod porządkowania odbitek graficznych oraz dokumentów tekstowych, często umożliwia ich precyzyjne datowanie, bywa kluczem do rozdzielenia stanów i wydań poszczególnych prac. Badania dostarczają też istotnych wiadomości na temat historii rynku wydawniczego. Porównywanie prostych, mechanicznie powielanych form, jakimi są filigrany i powtarzalne ślady struktur sita widoczne w strukturze kart, jest również dobrym testem na przydatność metod automatycznej analizy obrazu oraz wyszukiwania wizualnego dla potrzeb studiów wizualnych oraz historii sztuki.

W prezentowanym artykule podsumowano aktualny stan oraz zasady porządkowania materiału. Omówiono strategie projektowania aplikacji służących do ekspertyzy starego papieru. Zestawiono zrealizowane projekty, uwzględniając zasady ich działania. Oceniono możliwości rozwinięcia tego rodzaju narzędzi na potrzeby studiów wizualnych. Rozwiązania proponowane w zakończeniu wiążą się z pracami, jakie autorka niniejszego tekstu prowadzi w Gabinecie Rycin Polskiej Akademii Umiejętności Biblioteki Naukowej PAU i PAN w Krakowie, przy udziale dr Joanny Gancarczyk z Akademii Techniczno-Humanistycznej w Bielsku-Białej.

\section{REPOZYTORIA SIECIOWE JAKO LABORATORIUM PRAC NAD APLIKACJAMI DO ANALIZY WIZUALNEJ}

Współczesne projektowanie cyfrowych narzędzi przeznaczonych do badań nad papierem najczęściej powiązane jest z rozwijaniem nowych repozytoriów, które dokumentują poszczególne przykłady form filigranów lub struktur sita. Większość projektów, często zarzuconych po czasie, prowadzić miała do opublikowania odpowiednio uporządkowanej bazy danych. Z takimi założeniami realizowany był w drugiej połowie lat 90. XX wieku pionierski projekt Uniwersytetu Genew- 


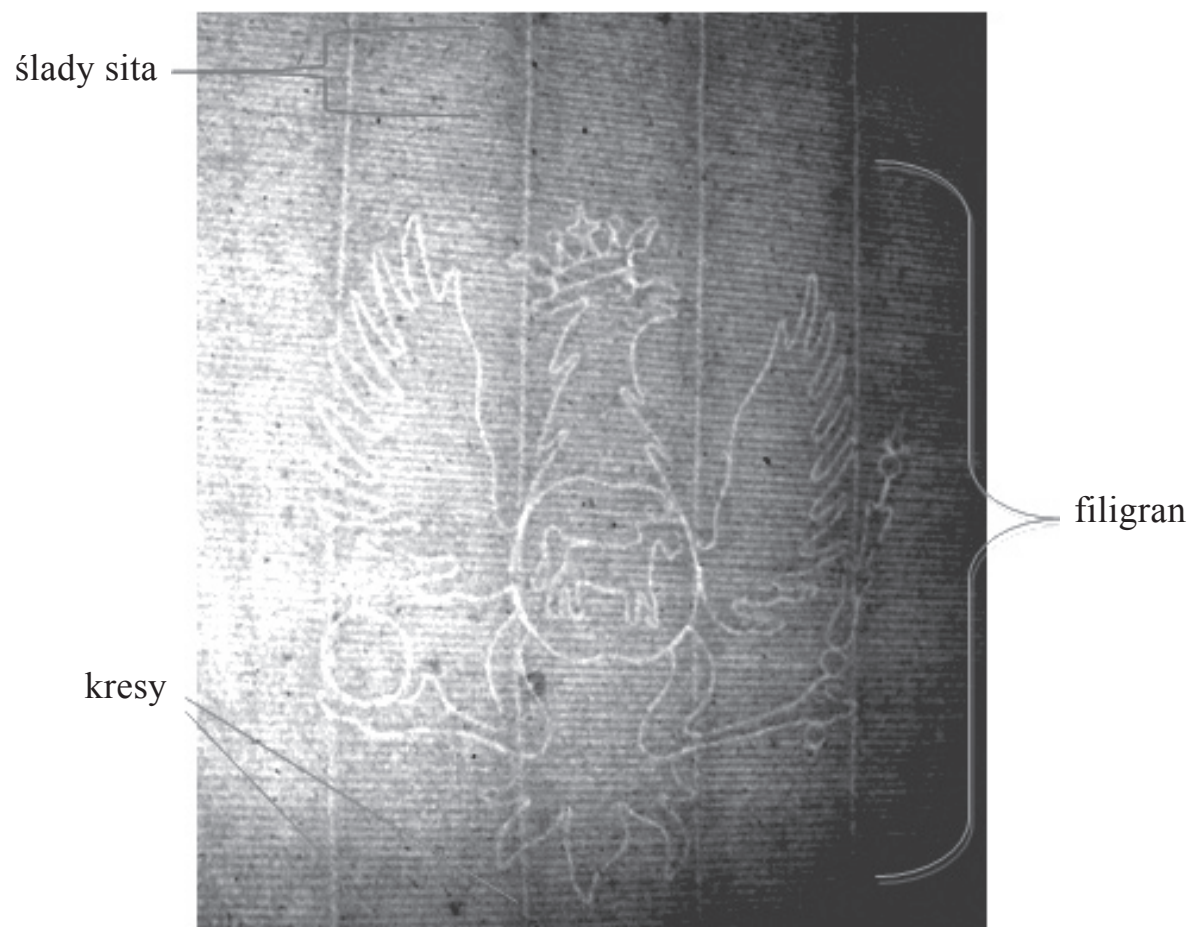

Ryc. 1. Filigran i struktura sita: schemat budowy 
skiego ${ }^{1}$. Zbudowaniem nowego repozytorium zakończyć planowano SHREW (SHape REtrieval of Watermarks) w latach 2000-2002². Wedle podobnych zasad działa też powstałe w 2006 roku Konsorcjum Bernsteinowskie ${ }^{3}$. Wśród mniejszych przedsięwzięć tego rodzaju wspomnieć można o najnowszych pracach nad tworzeniem katalogu dokumentującego strukturę sita na odbitkach graficznych Rembrandta, prowadzonych przy udziale Rijksmuseum ${ }^{4}$.

Ekspertyza papierów, powstałych przed połową XVIII wieku, polega przede wszystkim na porównywaniu śladów struktury sita oraz kształtów filigranu, odciśniętych w masie papierowej podczas produkcji karty. Filigrany, których odbicia nazywane są znakami wodnymi, stały się przedmiotem studiów już w drugiej połowie XIX stulecia. Wielotomowe katalogi utworzone z ich przerysów wydawano do końca XX wieku. Do 2014 roku udostępniono w sieci ponad pięćset tysięcy przerysów i zdjęć filigranów utrwalonych na starym papierze ${ }^{5}$. Szacować można, że stanowią one blisko połowę zawartości współczesnych zasobów tego typu ${ }^{6}$. W wersji cyfrowej publikowane są klasyczne dla tej dziedziny prace Charles-Moïse Briqueta i Gerharda Piccard ${ }^{7}$. Początki przenoszenia dokumentacji do sieci sięgają połowy lat 90. ubiegłego wieku. Przykładem może być archiwum Thomasa L. Gravella, w którym znalazły się niepublikowane przerysy C. M. Briqueta ${ }^{8}$. Drukowane tomy katalogów tego autora udostępniane są on-line od roku $2009^{9}$. W tym

${ }^{1}$ K. J. Riley, J. P. Eakins, Content-Based Retrieval of Historical Watermark Images: I - tracings, „Proceedings of the International Conference on Image and Video Retrieval”, Springer-Verlag, London 2002, s. 253-261; K. J. Riley, J. D. Edwards, i J. P. Eakins, Content-Based Retrieval of Historical Watermark Images: II - Electron Radiographs [w:] Image and Video Retrieval, Lecture Notes in Computer Science 2728, red. E. M. Bakker et al., Berlin, Heidelberg 2003, s. 131-140; Computer Vision Group, Demonstrations, 14.08.2007, http://web.archive.org/web/20070814091704/http:// vision.unige.ch/demos.html, 16.03.2015.

${ }^{2}$ Projekt prowadzony przez University of Northumbria w Newcastle upon Tyne; SHREW, 8.04.2005, http://web.archive.org/web/20050408073417/http://www.unn.ac.uk/iidr/research/wmarks/ wmarks.html, 16.03.2015.

${ }^{3}$ Bernstein - The Memory of Paper, Vienna 2009, http://www.memoryofpaper.eu:8080/BernsteinPortal/appl_start.disp, 16.03.2015.

${ }^{4}$ Współpraca Rijksmuseum i Morgan Library \& Museum; Johnson C. R., i et. al., Laid Paper Mold-Mate Identification via Chain Line Pattern (CLiP) Matching of Beta-Radiographs of Rembrandt's Etchings, „New Directions in the Study of Rembrandt and His Circle”, 2013, s. 1-17.

${ }^{5}$ E. Wenger, Paper and Watermarks Databases, Vienna 2009, 30.11.2010, https://www.google. com/maps/d/viewer?mid=zBbCIONHeDkA.kHCAxKnByb-w\&hl=en, 24.02.2015.

${ }^{6}$ Tamże.

7 Por. Landesarchiv Baden-Württemberg, Wasserzeichen-Informationssystem - Projektbeschreibung, b.d., http://www.wasserzeichen-online.de/wzis/projekt/projektbeschreibung_de.php, 24.02.2015.

${ }^{8}$ Wiosną 1995 roku kolekcję udostępniono w systemie BBS, który umożliwiał dostęp do bazy ograniczonej grupie użytkowników. Rok później pojawiła się jej pierwsza edycja w nowym wówczas formacie HTML D. W. Mosser i E. W. I. Sullivan, Gravell Project Description, b.d., http://www. gravell.org/description.php?\&\&offset=\&rectotal=\&query=, 24.02.2015.

${ }^{9}$ Początkowo w ramach projektu: Laboratoire de Médiévistique Occidentale de Paris i Österreichische Akademie der Wissenschaften, Briquet Online, b.d., http://www.ksbm.oeaw.ac.at/_scripts/ php/BR.php, 24.02.2015. 


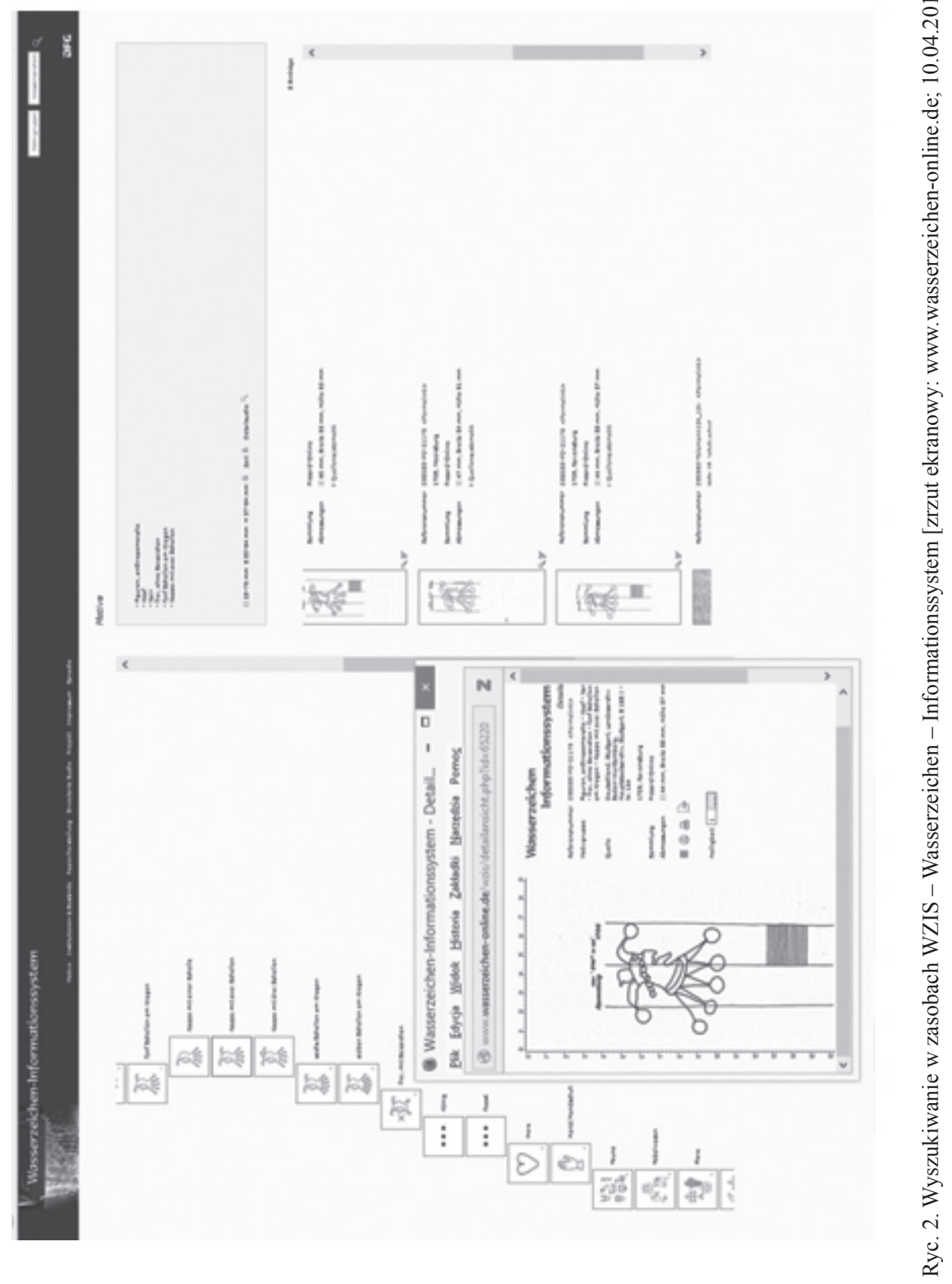

(C) Copyright by Polska Akademia Umiejętności \& Autorzy, Kraków 2015 


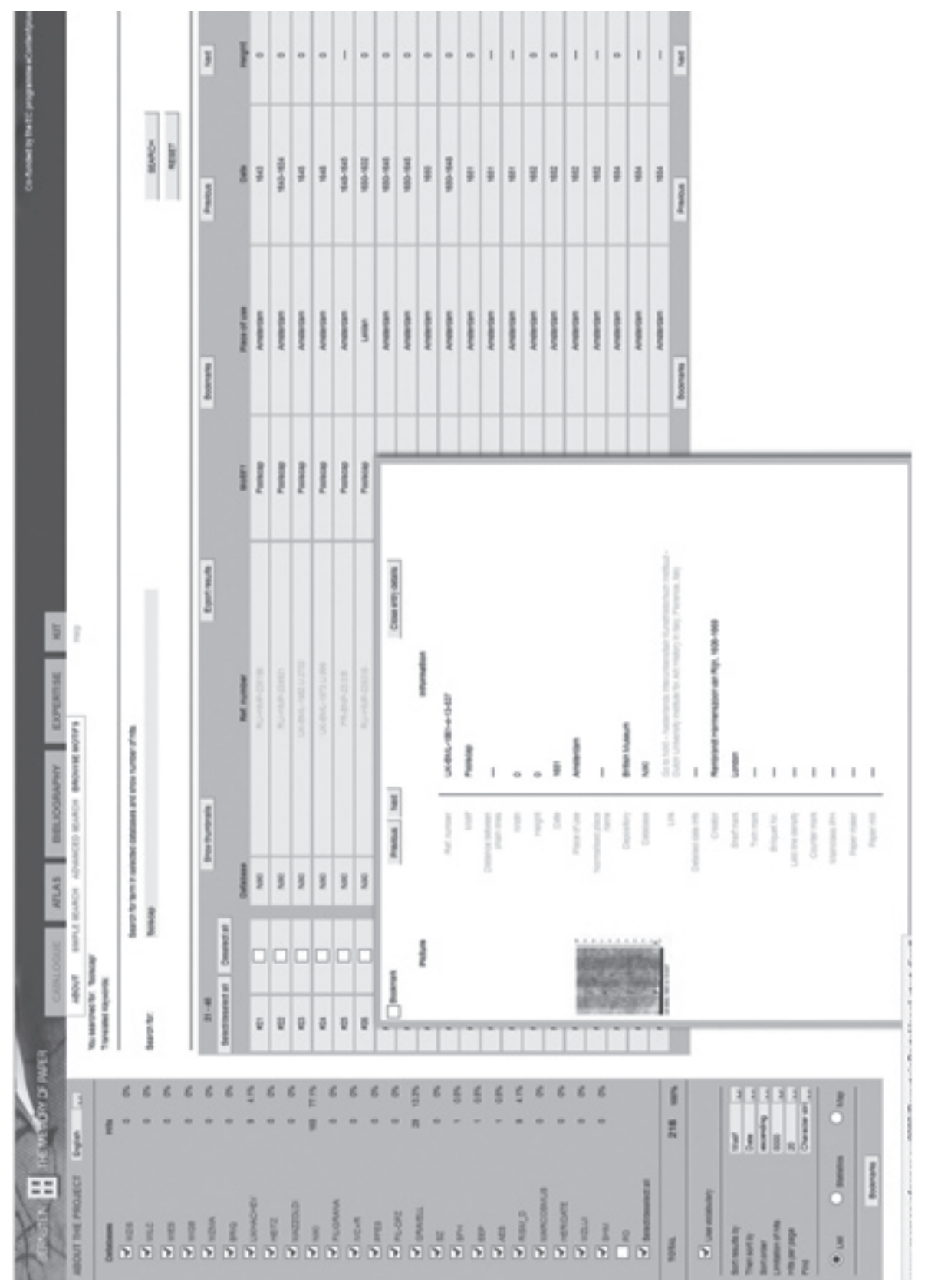

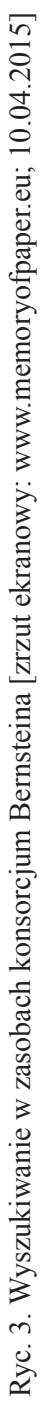

(c) Copyright by Polska Akademia Umiejętności \& Autorzy, Kraków 2015 
samym okresie zdigitalizowano spuściznę Gerharda Piccard. Prace nad uporządkowaniem niepublikowanych przerysów trwały od roku 2002. Po czterech latach całość zasobów, łącznie z tomami 3-17 katalogu Piccarda została udostępniona online.

Rosnące stopniowo kolekcje zaczęto scalać ze sobą około $2010^{10}$. W 2009 otwarto wspomniany portal Bernsteina, w którym pojawiły się początkowo cztery bazy danych ${ }^{11}$. Pod koniec 2014 roku była to największa platforma do badania filigranów na starych papierach. O funkcjonowanie Konsorcjum Bernstainowskiego dba Emanuel Wenger pracujący dla VISKOM - komisji, która zajmuje się wizualizacją w nauce, afiliowanej w Austriackiej Akademii Nauk ${ }^{12}$. Platforma „Memory of Paper” Bernsteina jest obecnie największą wyszukiwarką znaków wodnych. Pod koniec 2014 roku łączyła dwadzieścia trzy repozytoria. Głównym jej zasobem jest z kolei Wasserzeichen-Informationssystem (WZIS) rozwijane od 2010 roku przy udziale bibliotek niemieckich. WZIS powstał pod auspicjami Deutsche Forschungsgemeinschaft. Projekt dostarcza platformie Bernsteinowskiej ponad sześćdziesięciu procent rekordów.

Cechą charakterystyczną tych katalogów jest rezygnacja $\mathrm{z}$ opisu form filigranu, który stopniowo zamienia się w swojego rodzaju kod. Sygnatura rekordu bazy jest algorytmem zawierającym informacje o miejscu pochodzenia dokumentu. Przeniesienie materiału do cyfrowych baz danych umożliwiło prezentowanie wyników kwerend w formie wizualizacji statystycznych ${ }^{13}$.

Sposób zarchiwizowania części repozytoriów pozwala na tworzenie map ${ }^{14}$. Problemem pozostaje porządkowanie zebranego materiału ikonograficznego względem kształtu ${ }^{15}$. Wyszukiwanie wizualne form filigranów, pomijające hierarchiczny tezaurus oraz automatyczny pomiar struktur sita pozostają głównym obszarem działań dla projektantów.

${ }^{10}$ Por. statystyki w: Bernstein - The Memory of Paper: Catalogue, Vienna 2009, http://www. memoryofpaper.eu:8080/BernsteinPortal/appl start.disp, 16.03.2015.

${ }^{11}$ E. Wenger, Paper and Watermarks Databases, op. cit.

${ }_{12}$ Konsorcjum zbudowało swoją platformę w sieci w ramach grantów realizowanych w latach od 2006 do 2009. Prace koordynował Emanuel Wegner.

${ }^{13}$ Porównaj: http://www.wasserzeichen-online.de/wzis/struktur.php?klassi=006; Sama forma wizualizacji danych różni się $\mathrm{w}$ obu repozytoriach. Wyniki kwerend repozytorium niemieckiego są nanoszone na osie współrzędnych. Daje to możliwość wglądu w sumę wyników bez utraty wglądu w pojedyncze odniesienia.

${ }^{14}$ Podobne obrazy statystyczne uzyskiwać można dla WZIS (Wasserzeichen-Informationssystem).

${ }^{15} \mathrm{~W}$ obu repozytoriach zastosowano rozbudowaną klasyfikację kształtów. Hierarchiczna struktura katalogu pozostaje otwarta. Jest wzorowana na podziałach wprowadzonych przez G. Piccarda. Zawiera ponad trzydzieści motywów. Te zaś podzielono na ponad pięćset grup. Dotarcie do poszukiwanego przykładu wymaga zazwyczaj pokonania pięciu, sześciu stopni wyszukiwania. Tezaurus ujednolicono kosztem rozdrobnienia kategorii. Hierarchia działa jedynie dla kolekcji, w których Bernstein został zmodyfikowana przez WZIS. 


\section{ANALIZA ŚLADÓW SITA, PORÓWNYWANIE KSZTAŁTU FILIGRANÓW: METODY I ICH REALIZACJE}

W opracowaniu z roku 2005, poprzedzającym założenie wiedeńskiej platformy, sformułowano zadania, jakie miałyby wypełniać połączone z nią aplikacje do analizy papieru ${ }^{16}$. Wśród nich wymieniono automatyczne wzmocnienie śladów sita i filigranów oraz oddzielanie tej struktury od reszty obrazu, automatyczne wykonywanie pomiaru gęstości sita i rozstawu kres oraz wyszukiwanie identycznych kształtów filigranów w bazie danych ${ }^{17}$.

Konsekwencją sformułowania tych postulatów były propozycje dostosowania doświadczeń z zakresu komputerowej analizy obrazu do specyfiki zdjęć i rysunków dokumentujących filigrany. W ciągu dziesięciu lat od czasu powstania cytowanej noty udało się rozwiązać większość wymienionych tam problemów. Korzystanie z efektów tych prac pozostaje jednak dość ograniczone. Stworzone aplikacje nie zostały w pełni połączone z zasobami publikowanymi w sieci. Większość nie działa też samodzielnie. Jest dostępna dla użytkowników graficznych pakietów programu Matlab.

Programem łączącym funkcje wypunktowane na bersteinowskiej liście miał być „watermark toolbox". Ostatecznie opublikowano go w wersji zredukowanej do ,watermark toolkit" ${ }^{18}$. Aplikacja Wiktora Karnaukhova jest typowym systemem zarządzania bazą danych, dostosowanym do archiwizacji znaków wodnych. Służy do tworzenie repozytoriów wedle standardu katalogów WZIS i Bernsteina. Narzędzie generuje numer katalogowy, w którym zakodowane są miejsca pochodzenia dokumentu, wedle algorytmu stosowanego przez niemieckie repozytorium. Umożliwia przyporządkowanie dodawanego egzemplarza do hierarchicznego tezaurusa. Ułatwia zanotowanie wysokości i szerokości badanego znaku, jego odległości od kres oraz porównanie kształtów badanego filigranu. Funkcje te nie są jednak wykonywane automatycznie, wymagają ingerencji użytkownika. Funkcja porównywania kształtu ma pomóc w odnajdywaniu wariantów tego samego znaku, rozróżnianiu jego typów. Wymaga nałożenia na badany obraz półprzezroczystej warstwy z rysunkiem filigranu, do którego chcemy obraz dopasować. Ocena zgodności pozostawiona jest użytkownikowi. Program notuje wyniki pomiarów.

Poza bersteinowską wersją ,watermark toolkit” funkcjonuje obecnie grupa małych aplikacji, które pozwalają pracować bezpośrednio na plikach graficznych. Większość współdziała z Matlabem wykonując analizę obrazu w zakresie ograniczonym do jednego, dwóch zadań. Narzędzia te są świadectwem stopniowego

${ }^{16}$ V. Atanasiu, Paper Study Toolbox Overview, 2005, http://www.bernstein.oeaw.ac.at/twiki/ bin/viewfile/Main/ImageProcessing@filename=atanasiu2005___Paper_Study_Toolbox_Overview. pdf, 16.03.2015.

${ }^{17}$ Pojawił się też wspomniany wyżej postulat stworzenia narzędzi do statystycznej wizualizacji danych, ich nanoszenia na mapy. Wspomniano o funkcjach generujących raporty na temat zawartości katalogu, publikujących wyniki dokonanych pomiarów.

${ }^{18}$ Watermark Toolkit: Version: 1.0.11.10; User Manual, Vienna 2009, http://www.memoryofpaper.eu:8080/kit/doc/UserManual.pdf, 16.03.2015. 
uniezależnienia prac nad cyfrową analizą papieru od przedsięwzięć związanych $\mathrm{z}$ katalogowaniem materiału. Metody, które stanowią ich podstawę proponowano wykorzystać do badań nad papierem w latach 2001-2004 czego przykładem są prace Vlada Atanasiu, związanego wówczas z wiedeńskim Viskomem, oraz zespołu J.C.A. van der Lubbe $z$ Uniwersytetu Technicznego w Delft ${ }^{19}$. Narzędzia umożliwiają kontrolowane wzmacnianie lub redukcję struktur takich jak: kresy, sito, czy rysunek filigranu. Ich precyzyjne wydobycie i oddzielenie od reszty obrazu (segmentacja) jest warunkiem koniecznym dla przeprowadzenia dalszych pomiarów i rozwinięcia aplikacji, które umożliwiają porównywanie kształtów.

Wśród twórców tego rodzaju narzędzi przeważył pogląd, iż najlepsze efekty przynosi kombinacja porównywania śladu kres i $\operatorname{sita}^{20}$. Metoda rekomendowana była do badania odbitek w 1984 przez van der Meulena ${ }^{21}$. Z jego obserwacji wynikało, że odległości pomiędzy kresami na danym sicie różnią się od dziesięciu do dwudziestu procent. W starszych opracowaniach przyjmowano, że średnia odległość pomiędzy kresami pozwala na identyfikację odbitek, które wyszły z jednego sita. Mark van Staalduinen wykazał, że kresy identyfikują karty jednego nakładu precyzyjniej niż odcisk sita, ale pewną identyfikację zapewnia dopiero kombinacja tych pomiarów ${ }^{22}$. Późniejsze badania nad odbitkami Rembrandta wykazały, że dopiero sekwencja powyżej trzech odcinków pomiędzy kresami jest niepowtarzalna ${ }^{23}$.

Dając pierwszeństwo analizie wzorów sita, większość współczesnych projektantów proponuje narzędzia do analizy obrazu papierów, wykorzystujące dyskretną

19 J. C. A. van der Lubbe, E. P. van Someren, and M. J. T. Reinders, Dating and authentication of Rembrandt's etchings with the help of computational intelligence [w:] International Cultural Heritage Informatics Meeting, Milan 2001, s. 485-49; V. Atanasiu, Le traitement des images et son application à l'histoire du papier - La mesure à grande échelle de la densité de vergeures, "Gazette du Livre médiéval", 41 (2002), s. 31-41; Tenże, Assessing paper origin and quality through large-scale laid lines density measurements [w:] M. Livesey (wyd.), Paper as a medium of Cultural Heritage. Archeology and Conservation (Proceedings of The 26th Congress of the International Paper Historians Association, 30 August-6 September 2002, Rome, Verona 2004, s. 172-184.

${ }^{20}$ M. van Staalduinen, J. C. A. van der Lubbe, E. Backer, P. Paclik, Paper retrieval based on specific paper features: Chain and laid lines [w:] Proceedings of International Workshop on Multimedia Content Representation, Classification and Security, 2006, s. 346-353.

${ }^{21}$ D. L. Vander Meulen, The Identifcation of Paper without Watermarks: The Example of Pope's 'Dunciad', „Studies in Bibliography, vol. 37, 1984, s. 58-81.

${ }^{22} \mathrm{http}: / /$ mywebpage.netscape.com/atanasiuvlad/bluenile. 2002. 4. J. C. A. van der Lubbe, E. P. van Someren, M. J. T. Reinders, Dating and authentication of rembrandt's etchings with the help of computational intelligence [w:] International Cultural Heritage Informatics Meeting, Milan 2001, s. 485-492.

${ }^{23}$ Zauważono, że porównanie trzech odległości pomiędzy kresami może dać wynik pozytywny dla papierów oznaczonych różnymi filigranami. Kombinowanie wyników ze śladami sita redukuje potrzebę dopasowywania dłuższej sekwencji odległości pomiędzy kresami. Wykrywanie kres proponowane przez zespół amerykański ma na celu stworzenie katalogu odbitek Rembrandta, utrwalonych na papierach bez znaków wodnych. Dwie trzecie zachowanych odbitek tego autora nie ma znaku wodnego; por. C. R. Johnson et. al., Laid Paper Mold-Mate Identification via Chain Line Pattern (CLiP) Matching of Beta-Radiographs of Rembrandt's Etchings, ,New Directions in the Study of Rembrandt and His Circle", Herstmonceux 2013, s. 1-17. 
transformację Fouriera ${ }^{24}$. Regularne ślady tworzą sekwencje równoległych linii jaśniejszych i ciemniejszych na przemian. $Z$ tej racji łatwo je wyodrębnić przy użyciu filtrów fourierowskich. Do regulowania widoczności śladów sita jako pierwszy zaaplikował je Vlad Atanasiu, tworząc w latach 2003-2005 program „Blue Nile”25. Uzupełnił go aplikacją „AD751”, która liczy ich gęstość ${ }^{26}$. Ich ilość przypadająca na jeden centymetr karty stanowi jedną z podstaw identyfikacji papieru. W oparciu o podobne założenia działa także aplikacja „Paper Analysis Tool”, przygotowana przez zespół z Delft w roku $2009^{27}$. Program umożliwia zarówno wzmacnianie, jak i liczenie odległości pomiędzy śladami. Projektowanie aplikacji poprzedziły obserwacje przeprowadzone na tysiącu próbkach papieru. Pozwoliło to założyć, że gęstość sita wnosi od 5 do 15 linii na jeden centymetr powierzchni. W konsekwencji program wzmacnia tylko elementy, które spełniają ten warunek. Funkcja pozwala też redukować widoczność struktur sita. Obraz przekształcony przy użyciu filtru fourierowskiego nie jest ostatecznym wynikiem prac programu. Zostaje użyty w charakterze maski, która umożliwia odjęcie śladu linii od reszty obrazu, wyczyszczenie go ze struktur sita. „Paper Analysis Tool” umożliwia także automatyczne pomiary odległości pomiędzy kresami. W oparciu o metodę pokrewną transformacji Fourierowskiej opublikowano także aplikację „Quality Enhancement Tol”, zaopatrzoną w filtr Gabora poprawiający ogólną jakość obrazów struktur starego papieru ${ }^{28}$.

Narzędzia porównujące formy filigranów stanowią odrębną grupę aplikacji przeznaczonych do badań papieru. Praca nad nimi wymaga zastosowania metod umożliwiających oddzielenie i identyfikację nie powtarzalnego wzoru, ale kształtu złożonego z giętkich konturów.

Uwidocznienie filigranów w strukturze obrazu ułatwiać ma „Automatic Watermark Detection Tool”. Program wykrywa odcień i szerokość rysunku linii znaków wodnych. Wzmacnia ich rysunek, modyfikując odpowiednio histogram obrazu ${ }^{29}$.

Ze wzglądu na trudną do przeprowadzenia segmentację obrazów, prace nad aplikacjami do badań filigranów są prowadzone z myślą o wykorzystaniu dokumentacji rysunkowej znaków wodnych. Zespół Uniwersytetu Technicznego z Delft zapropo-

${ }^{24}$ M. van Staalduinen, Techreport: Enhancement of Paper Reproductions Generated by X-ray or Backlight Imaging for Several Applications, Delft 2007, s. 1-7 http://prlab.tudelft.nl/sites/default/ files/Enhancement_techreport.pdf, 17.03.2015

${ }^{25}$ BlueNile: Documentation, b.d., http://www.bernstein.oeaw.ac.at/software/bluenile/, 17.03. 2015.

${ }^{26}$ Powstała w 2005 roku http://www.bernstein.oeaw.ac.at/ad751/index.html; V. Atanasiu, Assessing paper..., s. $172-184$.

27 Por. Bernstein: Deliverable no. 25, ref. D3.2 Tools \& databases integrated AIE, 2009, http:// www.bernstein.oeaw.ac.at/twiki/pub/Main/DocumentsArchive/Del32_D7.8_Final_Project_Report. pdf, 17.03.2015.

${ }_{28}^{28}$ B. Pourebrahimi, J. C. A. van der Lubbe, A Novel approach for Noise Reduction in the Gabor time-Frequency Domain [w:] Proceedings of International Conference on Computing Vision Theory and Applications (VISAPP), Lisbon 2009, s. 22-27.

${ }^{29}$ Aplikacja działa we współpracy z Matlabem 7, z wykorzystaniem bibliotek: Image Processing Toolbox oraz DipImage Toolbox, w zależności od wielkości obrazu proces może potrwać kilka minut. 
nował program służący do porządkowania zdigitalizowanego katalogu Piccarda ${ }^{30}$. Pierwszym zadaniem, jakie wykonuje aplikacja, jest oddzielenie rysunku filigranu od szkicu kres, i ręcznie wpisanej noty, które składają się na standardowy rysunek tego zasobu. Autorzy programu potraktowali te elementy jako osobne, schematycznie rozmieszczane w strukturze obrazu obiekty (binary large objects). Program wykrywa je za pomocą algorytmów, które dopasowują kształty takiego obiektu do uprzednio zdefiniowanego wzorca (np. kresy rozpoznawane są automatycznie jako dwie pionowe linie). Wszystkie całości poza filigranem zostają następnie usuwane. Jak deklarują autorzy programu operacja udaje się w osiemdziesięciu czterech procentach, prawie jedna czwarta operacji wymaga korekty użytkowników.

Właściwości linii tworzących zarys znaku wodnego wzięto pod uwagę w projekcie aplikacji umożliwiającej wyszukiwanie identycznych filigranów, skonstruowanej na wewnętrzny użytek konsorcjum Bernsteina ${ }^{31}$. Rozważono profil konturu (jednakowy w każdym miejscu), jego kontrast (różnicę natężenia szarości w stosunku do tła), szerokość, kontynuację (połączone punkty linii), i długość linii. W celu wyszukania identycznego kształtu na obraz filigranu zostaje ograniczony ściśle doń przylegającym prostokątnym obramieniem. Na kadr zostaje nałożona siatka, która dziali go na równe segmenty. Dla każdego z nich odnotowana zostaje liczba pikseli reprezentujących linie filigranu. W ten sposób powstaje ciąg liczb, które identyfikują dany znak.

W ocenie projektantów metoda jest dogodna dla porównywania znaków wodnych. Nie wystarcza to jednak do zestawiania grup podobnych kształtów, a co za tym idzie porządkowania i tworzenia katalogów. Nie jest też całkowicie automatyczna, wyniki wymagają kontroli użytkownika, identyczny filigran pojawia się na pierwszej pozycji w odpowiedzi na sześćdziesiąt procent wyszukiwań ${ }^{32}$. Jej wadą jest brak elastyczności. Porównanie odbywa się na zasadzie trafiony - nie trafiony. Wynik pomiaru nie identyfikuje cech kształtu, ale konkretny obraz - jest zależny od obrotu, rozdzielczości oraz przesunięcia form, o precyzji rysunku nie wspominając.

Metody, które eliminowały ograniczenia wynikające z rotacji i zmiany skali filigranu proponowano w starszych, zarzuconych przed powstaniem platformy bersteinowskiej projektach. Miały one umożliwić odnalezienie nie tylko tożsamych, ale i zbliżonych kształtem filigranów. Pierwsze z nich testowano w drugiej połowie lat $90^{33}$.

${ }^{30}$ P. Rückert, S. Hodeček, i E. Wenger, Bull's Head and Mermaid: The History of Paper and Watermarks from the Middle Ages to the Modern Period; Booklet and Catalogue of the Exhibition Presented by the Landesarchiv Baden-Württemberg, Hauptstaatsarchiv Stuttgart and the Austrian Academy of Sciences, Kommission Für Schrift- und Buchwesen Des Mittelalters, Vienna, Landesarchiv Baden-Württemberg, Hauptstaatsarchiv Stuttgart 2009, s. 110.

${ }^{31}$ H. Moreu Otal, J. C. A. van der Lubbe, Isolation and Identification of Identical Watermarks within Large Databases [w:] A. Bienert, G. Stanke, J. Hemsley [wyd.], EVA 2008 Berlin - Konferenzband: Elektonische Medien \& Kunst, Kultur, Berlin 2008, s. 106.

${ }^{32}$ Tamże.

${ }^{33}$ C. Rauber, T. Pun, P. Tschudin, Retrieval of images from a library of watermarks for ancient paper identification [w:] EVA 97, Elektronische Bildverarbeitung und Kunst, Kultur, Historie, Berlin 1997 
Zespół Uniwersytetu Genewskiego projektując bazę danych dla Szwajcarskiego Muzeum Papieru zakładał, że wyszukiwanie kształtem będzie miało na celu dopasowanie obrazu do jednego $\mathrm{z}$ typów wyróżnionych uprzednio $\mathrm{w}$ tezaurusie kata$\operatorname{logu}{ }^{34}$. W tym celu starano się wyznaczyć swego rodzaju matematyczny wzorzec każdego z nich. Wzięto pod rozwagę kombinację kilku pomiarów. Precyzję wyszukiwania miało zwiększyć między innymi zapisanie ilości regionów (ograniczonych konturem powierzchni), składających się na daną formę. Dokumentowano też ich wzajemne ułożenie względem siebie. W tym celu zastosowano skomplikowaną procedurę, która miała określić kolejność zapisywania położenia tych fragmentów niezależnie od obrotu i skalowania. Polegała ona na wyłonieniu trzech największych powierzchni oraz zaznaczeniu pozycji ich centroid. $Z$ tymi trzema były łączone pozostałe mniejsze fragmenty. Do pomiarów dodano także ilość i pozycję przecięć konturów filigranu. Uwzględniono ilość czarnych pikseli (rysunek) w stosunku do jasnych (tło) w prostokątnych ramach dopasowanych ściśle do kształtu ${ }^{35}$. Przyjmowano, że da to pojęcie o stopniu skomplikowania formy filigranu. Ze względu na ówczesne ograniczenia mocy obliczeniowych maszyn wyszukiwanie mogło działać w oparciu o wyniki pomiarów wprowadzane numerycznie przez użytkownika. Złożoność metody czyniła ją w zasadzie niemożliwą do zrealizowania.

Autorzy świadomi ograniczeń narzucanych przez złożone algorytmy poszukiwali alternatywy metodach, polegających na uchwyceniu kształtu całego filigranu wedle jednej zasady. Jednym z ciekawszych wyjść, jakie zaproponowano, było porównywanie promienistych histogramów figur ${ }^{36}$. Wyznaczano je od punktu centralnego (środka ciężkości, centroidy) danej formy. Histogramy składały się zawsze z szesnastu części. Wartość każdej odpowiadała ilości czarnych pikseli (rysunek), które znalazły się wewnątrz odpowiedniej części promienistego podziału. Jeżeli histogramy wykazują podobieństwo - dwa znaki również są klasyfikowane jako podobne.

Intuicja co do skuteczności porównywania wedle ogólnych cech obrazu wyrażała się również w kierunku poszukiwań twórców projektu SHREW. Proponując metody porównywania kształtów, autorzy wzięli pod uwagę pomiary, które wypunktowano w opublikowanym wówczas standardzie opisu zawartości plików graficznych i filmowych - MPEG7. Przewidziano w nim możliwość odnotowania w metadanych pliku deskryptorów kształtu oraz konturów danego obiektu ${ }^{37}$. Naj-

${ }^{34}$ Tamże.

${ }^{35}$ Tamże: "the respective location of the regions. The centres of gravity of the three main regions are selected to build a new normalised coordinate frame. The largest region is the origin of the new coordinate frame and the two other regions form the two independent coordinate axes. The remaining regions from the watermark are then described in this ne frame by the means of two cardinals. This description provides a morphological representation of the watermark and is invariant to rotation, translation and scaling".

36 Tamże.

${ }^{37}$ Content-based retrieval of historical watermark images: I - tracings..., s. 253-261; A. J. E. Brown, R. Mulholland et al., Evaluating a Shape Retrieval System for Watermark Images [w:] Digital Art History: Computers and the History of Art (CHArt), 17th International 
skuteczniejszym okazał się pierwszy z nich. Podstawą jego wyznaczenia była transformacja kątowo promieniowa ART. Figura rozpatrywana jest wówczas względem współrzędnych biegunowych. Jej środek ciężkości umieszczony zostaje w centrum tego układu odniesienia. W praktyce oznaczało to zapisywanie dla każdego obrazu wartości momentu Zernike’a.

\section{WYSZUKIWANIE POZA REPOZYTORIUM: MODERNIZACJA STARYCH I KONSTRUKCJE NOWYCH NARZĘDZI NA POTRZEBY STUDIÓW WIZUALNYCH}

Zdaniem projektantów współczesnych aplikacji, służących do analizy papieru, porównywanie kształtów filigranu nadal czeka na satysfakcjonujące rozwiązanie ${ }^{38}$. Rozwijanie tej metody jest korzystne nawet przy założeniu, że analiza wzorów sita wystarczy dla porządkowania odbitek graficznych. Filigrany mogą połączyć studia nad papierem z systematyzacją wiedzy o znakach towarowych, gmerkach i monogramach ${ }^{39}$. Orientacja w systemach oznaczeń wyrobów rzemiosła, dzieł sztuki, a nawet budowli architektonicznych może okazać się kluczowa dla otwarcia nowych perspektyw w studiach nad sztuką i komunikacją wizualną.

Mając na uwadze doświadczenia poprzednich zespołów, projektujących tego rodzaju narzędzia, warto wskazać rozwiązania, które zapewniają nowym aplikacjom pełniejsze wykorzystanie do analizy wizualnej. Wydaje się, że przy obecnym stanie badań korzystną może okazać się rezygnacja z kilku elementów uznawanych dotychczas za konieczne w ich funkcjonowaniu. Po pierwsze: kolejne aplikacje porównujące kształty filigranów mogą powstawać niezależnie od projektów budowy kolejnych repozytoriów. Dość, że nowe narzędzie wykorzystamy do „znaczenia” obrazów, publikowanych w starszych zbiorach. Wyniki pomiarów wystarczy zapisać $\mathrm{w}$ formie metadanych każdego z przeanalizowanych przez program plików. Aplikację można zredukować do nakładki, współdziałającej z dowolną wyszukiwarką internetową. Umożliwi to ich późniejsze odnajdywanie w całości zasobów sieciowych. Pozwoli połączyć istniejące repozytoria. Po wtóre: projektując programy, które miałyby stać się częścią laboratorium badań wizualnych, warto zrezygnować z dążenia do całkowitej automatyzacji wyników pracy. Narzędzia przeznaczone dla studiów wizualnych mogą opierać się na metodach półautomatycznych, pozostawiając badaczom decyzję co do interpretacji wyników. Takie założenie poszerzy również możliwości wyboru metody wyszukiwania i analizy danego kształtu.

Conference, London, November 2001, s. 17-19; http://www.chart.ac.uk/chart2001/papers/mulholland.html\#12b.

${ }^{38}$ Bernstein: Deliverable no. 25, ref. D3.2 Tools \& databases integrated AIE, 2009, http://www. bernstein.oeaw.ac.at/twiki/bin/viewfile/Main/DocumentsArchive@filename=Deliverable25_D3.2.pdf, 16.03.2015.

${ }^{39}$ Por. ARTISAN: a prototype retrieval system for trade mark images, 12.04.2005, http://web. archive.org/web/20050412011436/http://www.unn.c.uk/iidr/papers/vineart/vineart.html, 16.03.2015. 


\title{
ANNA OLSZEWSKA \\ DIGITAL TOOLS IN THE ANALYSES OF THE PRINTS: REALIZED PROJECTS AND THE POSSIBILITIES OF THEIR DEVELOPMENT FOR THE NEEDS OF VISUAL STUDIES
}

\begin{abstract}
Summary
The present article discusses the strategy of designing the applications used to analyse old paper. It summarises the present state of arranging the material and compares the projects that have been realised. It also provides the assessment of the possibilities to develop these kinds of tools for the needs of visual studies. The solutions presented in the conclusion are connected with the work the author of this text does in the Print Room of the Polish Academy of Arts and Sciences of the Scientific Library of the Polish Academy of Sciences and the Polish Academy of Arts and Sciences in Cracow, in co-operation with Dr Joanna Gancarczyk from the University of Bielsko-Biała.

Modern design of the digital tools used in studies of paper is most often connected with the development of new repositories which document individual examples of the watermarks or the structures of the screens. That was the objective of the pioneering project realised in the mid $90 \mathrm{~s}$ of the $20^{\text {th }}$ century at the University of Geneva (C. Graham, Rauber, T. Pun, P. Tschudin). The construction of a specialised database was to complete SHREW (Shape Retrieval of Watermarks) in the years 2000-2002 (K. J. Riley, J. P. Eakins). Both projects were stopped after 2005. Nowadays, the Bernstein Consortium, established in 2006, operates according to similar rules (E. Wenger et al.).

According to the designers of modern applications used in the paper analyses, the technique of comparing the shapes of a watermark is still waiting for a satisfying solution. Taking into consideration previous experiences, while creating new programmes we should give up the urge to entirely automatise the results of our work. The tools used in visual studies can be based on half - automatic methods, leaving the decision on how to interpret the results to the researchers. Such an assumption will broaden the possibilities in the choice of a method used to search for and analyse a given shape. Watermarks can combine the studies of paper with the systemising our knowledge of trademarks, house marks and monograms. With the present state of the network database development, the next applications comparing their shapes can work independently from their repositories. The programmes can be used to "mark" the images; it is enough to record the results of the measurements in the form of metadata. The application reduced to a role of a front - end, co-operating with any internet search engine will make it easier to put together the collections published on the Internet.
\end{abstract}


(C) Copyright by Polska Akademia Umiejętności \& Autorzy, Kraków 2015 